\title{
ENGINEERING SCIENCES
}

\section{SYNTHESIS AND PROPERTIES OF THE DIPROPARGYL DIETER DERIVATIVE 2-BROMINE-2- NITRO-PROPANDIOL-1,3 (BRONOPOL)}

\author{
${ }^{1}$ Sc.D., Professor Makhsumov Abdulhamid \\ ${ }^{2}$ Assistant Auesbaev Alisher \\ ${ }^{I}$ Doctor of Chemistry, Professor of the Department of Chemical Technology of Oil and Gas \\ Processing, Honored Inventor of the Republic of Uzbekistan, Full Member of the Academy of Healing \\ of Uzbekistan, Academician A.S. Turon, Tashkent Institute of Chemical Technology, Uzbekistan. \\ ${ }^{2}$ Master of Tashkent Chemistry - Institute of Technology and Department of Chemical Technology of \\ Oil and Gas Processing, Uzbekistan
}

DOI: https://doi.org/10.31435/rsglobal_wos/30122019/6839

\section{ARTICLE INFO}

Received: 22 October 2019

Accepted: 11 December 2019

Published: 30 December 2019

\section{KEYWORDS}

Bronopol, 2-bromo-, 2-nitro propanediol - 1,3, dipropargyl diester, acetylenide, synthesis, dimethylformamide, tetroureas.

\begin{abstract}
The article is devoted to a comprehensive study of 2-bromo-2-nitropropanediol - 1,3 (bronopol) in order to expand the derivatives of bronopol as food products, preservatives, in all sectors of the national economy. The derivatives of dipropargyl diester 2 - bromo -, 2 - nitro propanediol - 1,3, $\gamma, \gamma^{\prime}$-dicopper (2-bromo-,2-nitro-dipropargyl diester) propanediol-1,3 (II), $\gamma, \gamma^{\prime}$-bis- (silver 2-bromo-, 2-nitro-dipropargyl ether) - propanediol-1,3 (III), mercury-bis- (propargyl ether) - 2 - bromo-, 2nitro-propanediol - 1, 3 (IV), $\left(\gamma, \gamma^{\prime}\right.$-dibromo-dipropargyl diester) - 2bromo-, 2-nitropropanediol-1,3 (VIII) were synthesized.. We also considered the preparation of $\gamma, \gamma^{\prime}$-diiodo-dipropargyl diester - 2-bromo-, 2-nitropropanediol-1,3 (V), bis (4,4'-pyrazolyloxymethylene) - 2 bromo -, 2 - nitro - propanediol - 1.3 (IX). The chemical properties of the 2-bromo-, 2-nitro-, dipropargyl diester of 1,3-propanediol-1,3 were studied, they learned that its $-C \equiv C-H$ group readily undergoes a substitution reaction with $\mathrm{Cu}_{2} \mathrm{Cl}_{2}, \mathrm{AgNO}_{3}, \mathrm{Hg}\left(\mathrm{OCOCH}_{3}\right)_{2}$ to produce acetylenides, and the obtained acetylenide can interact with iodine to produce new $\mathrm{R}-\left(\mathrm{OCH}_{2}-\mathrm{C} \equiv \mathrm{C}-\mathrm{I}\right)_{2}$ compounds. The article also describes the synthesis of 2-bromo, 2-nitro-1,3-propanediol bis $\left(4,4^{\prime}\right.$ pyrazolyl-hydroxymethylene) and their interactions with hexamethylenediisocyanate, which has an exceptionally super-high reactivity, to produce tetrourea derivatives at temperature $50-55^{\circ} \mathrm{C}$.
\end{abstract}

Citation: Makhsumov Abdulhamid, Auesbaev Alisher. (2019) Synthesis and Properties of the Dipropargyl Dieter Derivative 2-Bromine-2-Nitro-Propandiol-1,3 (Bronopol). International Academy Journal Web of Scholar. 12(42). doi: 10.31435/rsglobal_wos/30122019/6839

Copyright: (C) 2019 Makhsumov Abdulhamid, Auesbaev Alisher. This is an open-access article distributed under the terms of the Creative Commons Attribution License (CC BY). The use, distribution or reproduction in other forums is permitted, provided the original author(s) or licensor are credited and that the original publication in this journal is cited, in accordance with accepted academic practice. No use, distribution or reproduction is permitted which does not comply with these terms.

Introduction. The traditional method of synthesizing bronopol, mainly consists in first adding and then brominating. Non-polar toxic and flammable solvents such as ethyl acetate, carbon tetrachloride or dichloroethane must be used in the bromination reaction. The main salt formation of the nitro alcohol intermediate is not stable in the reaction, which is extremely disadvantageous for industrial production: therefore, it is necessary to improve its synthesis path by first brominating nitromethane with the formation of a stable intermediate bromonitromethane and then adding formaldehyde to the reaction to form bronopol. 
The currently intensively developing chemistry of acetylene derivatives of 1,3-propanediol (bronopol), pyrazoles, and urea compounds has attracted the attention of many researchers, both in Uzbekistan and abroad [1-10].

This is due, on the one hand, with the rich possibilities of various chemical transformations that acetylene esters, 2-bromo, 2-nitro-propanediol-1,3, as well as derivatives of pyrazole, urea groups in the molecules of one organic compound represent, and with on the other hand, with different properties valuable for the practical use of the most organic compounds with the above-linked groups.

2-Bromo-2-nitro-propanediol-1,3 or bronopol has a wide spectrum of antibacterial activity [11-12]. Bronopol is even used as a laboratory preservative for milk and as a biocide. Bronopol - found application in water treatment. At this end of use, large volumes of industrial water can be stored and recycled through large evaporative cooling towers, while smaller cooling towers can be used in hotels and public areas of the anti-water building used in air conditioning systems. Therefore, the selected bronopol biocide is effective for large dilutions with an inexpensive, non-volatile, non-aggressive and preferably non-foaming effect, and is also used in pool cleaning. In addition, bronopol is used as a biocide and preservative in technological fluids, paper mills, personal care products, metalworking fluids, fuel storage tanks oils, as well as in water-based paints, inks and adhesives [13-17].

Therefore, in order to expand the derivatives of bronopol as food products, preservatives, in almost all sectors, primarily in the food industries, cosmetics, chemical, pharmacy, medicine, and agriculture, derivatives of bronopol can be used. They are considered an important component to make food safe, leather, cosmetic, medicinal, pharmaceutical and many other sectors of the economy. Compared to other preservatives, bronopol has its advantages.

Results and discussion. The presence in the molecules of propanediol $-1,3$ bromine atoms, nitro-triple $(-\mathrm{C} \equiv \mathrm{CH})$ bonds, increases antifungal, biocidal, antiseptic, bactericidal, physiological, pharmacological, biological activity while reducing toxicity, and also exhibits antimicrobial, anticholesterol, anti-cancer and many other properties [18-24].

From the literature it is known that derivatives of dipropargyl ethers have various types of superbiological activity. For example, acetylene containing esters, nitro-bromine contained in one carbon, 1,3-propanedihydroxy possess growth-promoting, antimicrobial, antiseptic preservatives for dairy products, in the manufacture of cheese, which reduce bad cholesterol and blood sugar, as well as many other activities [25 -30].

In the literature [31-33], the synthesis of various $N, S$ acetylene compounds with a terminal triple bond is given. However, information on the synthesis of glycerol diacetylene compounds in the 1,3positions, and in the 2-position containing bromo and nitro groups and their derivatives of the type:

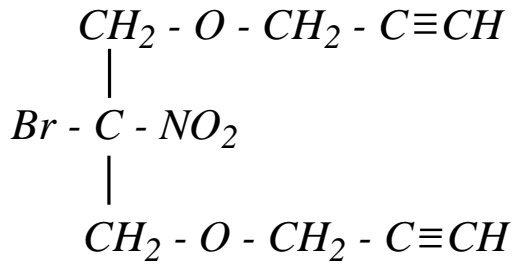

we have not found, these little-known compounds essentially represent a new kind of compounds whose properties have not been studied. In this regard, we obtained derivatives of the 1,3-dipropargyl diester of 2-bromo- 2-nitro-1,3-propanediol interacting with propargyl bromide in the presence of an organic solvent of 2-bromo-2-nitro- propanediol-1,3 according to the scheme:

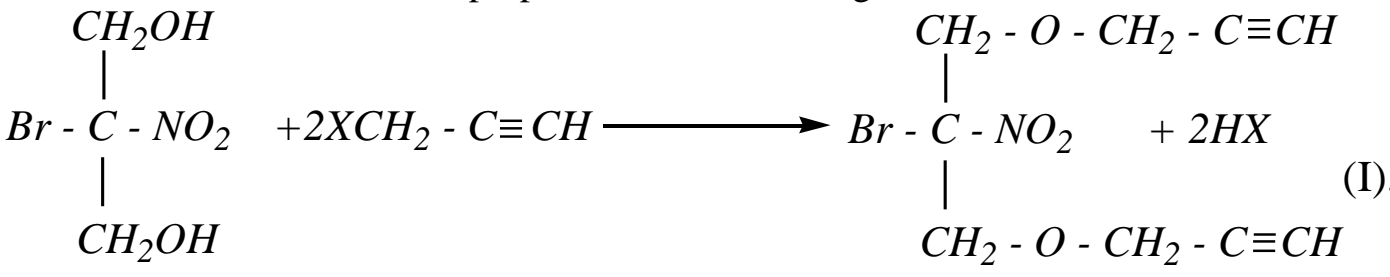

Where: $X=B r, C l, I$.

The obtained derivatives of 2-bromo-2-nitro-dipropargyl diester propanediol-1,3 are highly soluble substances in many organic solvents and sparingly soluble in water.

The physico-chemical parameters of the derivative of 2-bromo-2-nitro-dipropargyl 1,3propanediol (I) are shown in Table 1. 
Table.1. Physico-chemical parameters of 2-bromo-2-nitro-dipropargyl diester-1,3-propanediol.

\begin{tabular}{|c|c|c|c|c|c|c|c|c|c|}
\hline \multirow{3}{*}{ Structural formula } & \multirow{3}{*}{ 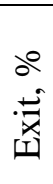 } & \multirow{3}{*}{ 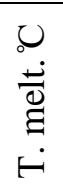 } & \multirow{3}{*}{$\approx$} & \multirow{3}{*}{$\begin{array}{c}\text { Gross } \\
\text { formula }\end{array}$} & \multicolumn{4}{|c|}{ Elemental analysis, $\%$} & \multirow[t]{3}{*}{$M_{M}$} \\
\hline & & & & & \multicolumn{2}{|c|}{ Calculated } & \multicolumn{2}{|c|}{ Found } & \\
\hline & & & & & $N$ & $B r$ & $N$ & $\mathrm{Br}$ & \\
\hline $\begin{array}{l}\mathrm{CH}_{2}-\mathrm{O}-\mathrm{CH}_{2}-\mathrm{C} \equiv \mathrm{CH} \\
\mathrm{Br}-\mathrm{C}-\mathrm{NO}_{2} \\
\mathrm{CH}_{2}-\mathrm{O}-\mathrm{CH}_{2}-\mathrm{C} \equiv \mathrm{CH}\end{array}$ & \begin{tabular}{l}
+ \\
\multirow{\sigma}{*}{}
\end{tabular} & $\begin{array}{l}a \\
\text { à } \\
\text { å }\end{array}$ & $\overrightarrow{0}$ & $\mathrm{C}_{9} \mathrm{H}_{10} \mathrm{NBrO}_{4}$ & $\begin{array}{l}5 \\
i\end{array}$ & 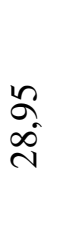 & $\begin{array}{l}\hat{\sigma} \\
\dot{\gamma}\end{array}$ & 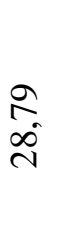 & हे \\
\hline
\end{tabular}

Purification of the 2-bromo-2-nitro-dipropargyl diester of 1,3-propanediol was carried out using preparative thin-layer chromatography on $\mathrm{Al}_{2} \mathrm{O}_{3}$ in the toluene system: hexane $=2: 5$. To prove the structure of 2-bromo-2-nitro-dipropargyl diester of propanediol-1,3, the method of IR- and UVspectroscopy was used (Table 2).

Table.2. IR- and UV- spectra of compounds (I).

\begin{tabular}{|c|c|c|c|c|c|c|c|}
\hline \multirow{2}{*}{ 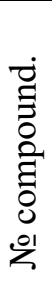 } & \multirow[b]{2}{*}{ Structural formula } & \multicolumn{5}{|c|}{ IR-spectra, $v, \mathrm{~cm}^{-1}$} & UV-spectra, nm \\
\hline & & $\begin{array}{c}1 \\
u \\
\text { III } \\
\text { un }\end{array}$ & $\underset{I I I}{J}$ & $\begin{array}{l}I^{N} \\
\vdots \\
1 \\
1\end{array}$ & $\begin{array}{l}0^{N} \\
\dot{1}\end{array}$ & $\begin{array}{l}\hat{0} \\
\vdots \\
u\end{array}$ & $-\mathrm{CH}_{2}-\mathrm{C} \equiv \mathrm{CH}$ \\
\hline I & $\begin{array}{l}\underset{\mid}{\mathrm{CH}}-\mathrm{O}-\mathrm{CH}_{2}-\mathrm{C} \equiv \mathrm{CH} \\
\mathrm{Br}-\mathrm{C}-\mathrm{NO}_{2} \\
\mathrm{CH}_{2}-\mathrm{O}-\mathrm{CH}_{2}-\mathrm{C} \equiv \mathrm{CH}\end{array}$ & $\vec{\sim}$ & $\frac{d}{m}$ & $\begin{array}{l}\text { ָे } \\
\text { In }\end{array}$ & \begin{tabular}{l}
$\hat{n}$ \\
\multirow{1}{n}{} \\
$\stackrel{n}{n}$ \\
$n$
\end{tabular} & to & $241-323$ \\
\hline
\end{tabular}

The chemical properties of 2-bromo-2-nitro-dipropargyl diester of propanediol-1,3 (I) were studied. It was found that the $-\mathrm{C} \equiv \mathrm{C}-\mathrm{H}$ group easily undergoes a substitution reaction with $\mathrm{Cu}_{2} \mathrm{Cl}_{2}$, $\mathrm{AgNO}_{3}, \mathrm{Hg}\left(\mathrm{OCOCH}_{3}\right)_{2}$ to produce acetylenide compounds (I) according to the following scheme:

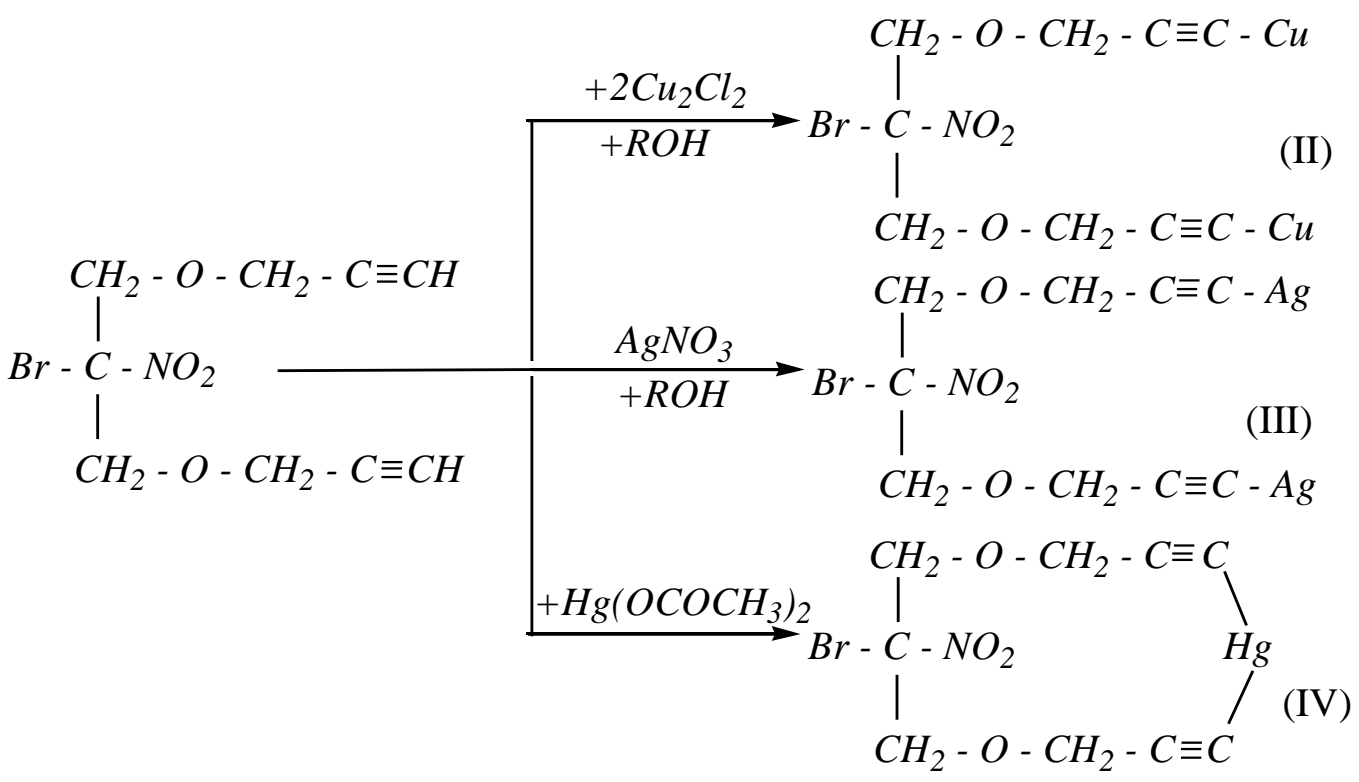

Of interest was the interaction of copper diacetylinide 2-bromo-2-nitro-dipropargyl diester propanediol-1,3 with iodine, in order to obtain new $R-\left(\mathrm{OCH}_{2}-\mathrm{C} \equiv \mathrm{C}-\mathrm{I}\right)_{2}$ little known compounds.

The reaction of compound II-IV with iodine was carried out in an environment of sulfuric ether at room temperature for 0.5-1 hours according to the following scheme: 


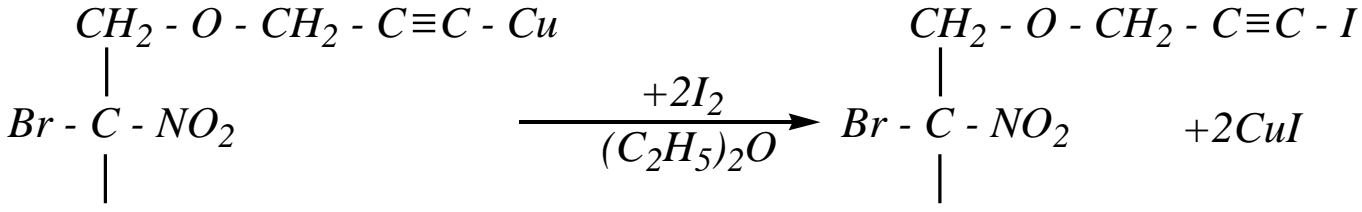

$$
\begin{aligned}
& \mathrm{CH}_{2}-\mathrm{O}-\mathrm{CH}_{2}-\mathrm{C} \equiv \mathrm{C}-\mathrm{Cu} \quad \mathrm{CH}_{2}-\mathrm{O}-\mathrm{CH}_{2}-\mathrm{C} \equiv \mathrm{C}-\mathrm{I} \\
& \mathrm{CH}_{2}-\mathrm{O}-\mathrm{CH}_{2}-\mathrm{C} \equiv \mathrm{C}-\mathrm{Ag}+\mathrm{I}_{2} \quad \mathrm{CH}_{2}-\mathrm{O}-\mathrm{CH}_{2}-\mathrm{C} \equiv \mathrm{C}-\mathrm{I} \\
& \mathrm{Br}-\mathrm{C}-\mathrm{NO}_{2} \quad \frac{+2 \mathrm{I}_{2}}{\left(\mathrm{C}_{2} \mathrm{H}_{5}\right)_{2} \mathrm{O}} \mathrm{Br}-\mathrm{C}-\mathrm{NO}_{2}+2 \mathrm{CuI} \\
& \mathrm{CH}_{2}-\mathrm{O}-\mathrm{CH}_{2}-\mathrm{C} \equiv \mathrm{C}-\mathrm{Ag} \quad \mathrm{CH}_{2}-\mathrm{O}-\mathrm{CH}_{2}-\mathrm{C} \equiv \mathrm{C}-\mathrm{I} \\
& \mathrm{CH}_{2}-\mathrm{O}-\mathrm{CH}_{2}-\mathrm{C}=\mathrm{C}-\mathrm{I} \\
& \underset{\mathrm{CH}}{\mathrm{CH}}-\mathrm{O}-\mathrm{CH}_{2}-\mathrm{C}=\mathrm{C}-\mathrm{CH}_{2}-\mathrm{C} \equiv \mathrm{C}
\end{aligned}
$$

\begin{tabular}{|c|c|c|c|c|c|c|c|c|c|c|c|}
\hline \multirow[b]{3}{*}{ № compound } & \multirow{3}{*}{ 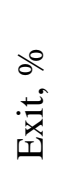 } & \multirow{3}{*}{ 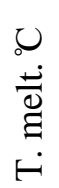 } & \multirow[t]{3}{*}{$\mathrm{R}_{\mathrm{f}}$} & \multirow[b]{3}{*}{ Gross formula } & \multirow[b]{3}{*}{$z$} & \multicolumn{6}{|c|}{ Elemental analysis, \% } \\
\hline & & & & & & & lcula & & & Foun & \\
\hline & & & & & & $N$ & $I$ & $\mathrm{Br}$ & $N$ & $I$ & $B r$ \\
\hline V & $\hat{\sigma}^{f}$ & $\begin{array}{l}\beth \\
\underline{b}\end{array}$ & 0,74 & $\mathrm{C}_{9} \mathrm{H}_{8} \mathrm{NI}_{2} \mathrm{BrO}_{4}$ & $\hat{\widehat{n}}$ & $\begin{array}{l}n \\
i\end{array}$ & $\begin{array}{l}8 \\
8 \\
\stackrel{\infty}{+}\end{array}$ & $\stackrel{ \pm}{\stackrel{ \pm}{Z}}$ &  & $\stackrel{\hat{\infty}}{\tilde{\gamma}}$ & $\stackrel{0}{2}$ \\
\hline VI & $\begin{array}{l}+ \\
\text { ڤ̆ }\end{array}$ & $\begin{array}{l}\infty \\
\stackrel{1}{I} \\
=\end{array}$ & 0,66 & $\mathrm{C}_{9} \mathrm{H}_{8} \mathrm{NI}_{2} \mathrm{BrO}_{4}$ & $\hat{\sim}$ & $\begin{array}{l}n \\
i \\
i\end{array}$ & $\begin{array}{l}8 \\
\infty \\
\infty\end{array}$ & $\stackrel{\Xi}{\stackrel{\Xi}{ت}}$ & $\sqrt{n}$ & $\underset{\infty}{\infty}$ & $\begin{array}{l}\infty \\
n\end{array}$ \\
\hline VII & ñ & $\begin{array}{l}\infty \\
\underline{b} \\
=\end{array}$ & 0,72 & $\mathrm{C}_{9} \mathrm{H}_{8} \mathrm{NI}_{2} \mathrm{BrO}_{4}$ & $\hat{\sim}$ & $\begin{array}{l}n \\
i \\
i\end{array}$ & $\begin{array}{l}8 \\
\stackrel{\infty}{+}\end{array}$ & $\frac{ \pm}{n}$ & $\begin{array}{l}\text { f } \\
\text { i }\end{array}$ & $\begin{array}{c}\overline{0} \\
\infty \\
+\end{array}$ & $\begin{array}{l}8 \\
2 \\
2\end{array}$ \\
\hline VIII & $\hat{\nabla}$ & $\begin{array}{l}\text { †े } \\
\text { ò }\end{array}$ & 0,61 & $\mathrm{C}_{9} \mathrm{H}_{8} \mathrm{NBr}_{3} \mathrm{O}_{4}$ & $\overrightarrow{\tilde{r}}$ & $\begin{array}{l}\text { ते } \\
\text { m. }\end{array}$ & & $\begin{array}{l}\text { in } \\
\text { nn }\end{array}$ & $\underset{\sim}{\stackrel{\Delta}{n}}$ & ' & $\frac{\infty}{n}$ \\
\hline
\end{tabular}

Physico-chemical characteristics (V-VIII) of the compounds are given in table. 3.

Table 3. Physico-chemical characteristics (V-VIII).

Buildings V-VIII are established by elemental analysis, IR-spectroscopy, and molecular weight (Tables 3 and 4). 
Table 4. IR spectra of compounds (V-VIII).

\begin{tabular}{|c|c|c|c|c|c|c|c|}
\hline \multirow[b]{2}{*}{ № compound } & \multicolumn{7}{|c|}{ IR-spectra, $v, \mathrm{sm}^{-1}$} \\
\hline & $\begin{array}{c}1 \\
u \\
\text { III } \\
\text { ú }\end{array}$ & $\underset{\text { III }}{J}$ & $\underbrace{\grave{\omega}}_{\text {III }}$ & $\begin{array}{c}1 \\
\mathbb{J} \\
1 \\
0 \\
1\end{array}$ & $\begin{array}{l}\text { वे } \\
1 \\
u\end{array}$ & $\begin{array}{l}0^{N} \\
\vdots \\
u\end{array}$ & $\underset{1}{i}$ \\
\hline $\mathrm{V}$ & 2214 & 2238 & - & 1114 & 660 & 1554-1376 & 2871 \\
\hline VI & 2217 & 2241 & - & 1113 & 663 & $1553-1376$ & 2873 \\
\hline VII & 2213 & 2236 & - & 1112 & 664 & $1393-1374$ & 2871 \\
\hline VIII & 2204 & - & 2224 & 1113 & 661 & $1554-1374$ & 2872 \\
\hline
\end{tabular}

To clarify the reactivity of the $-C \equiv C-$ group, intermolecular cyclization reactions were carried out, where 1,2-pyrazole derivatives of compounds (I) were obtained. Reactions in organic synthesis proceeding with the participation of a triple bond allow developing simple methods for the preparation of valuable nitrogen-containing five-membered heterocyclic compounds from a biological, pharmacological point of view, such as 1,2-pyrazoles, pyrroles, thiophenes containing various hetero atoms.

Based on the foregoing, previously unknown compounds were synthesized containing various hetero atoms $-C \equiv C-$, in connection with the fact on their basis various functional five-membered heterocycles with potentially very high pharmacological and biological activity can be obtained.

The synthesis of the derivative 1,2 - pyrazole (IX) was carried out by the interaction of the drug (I) with diazomethane according to the following reaction scheme:

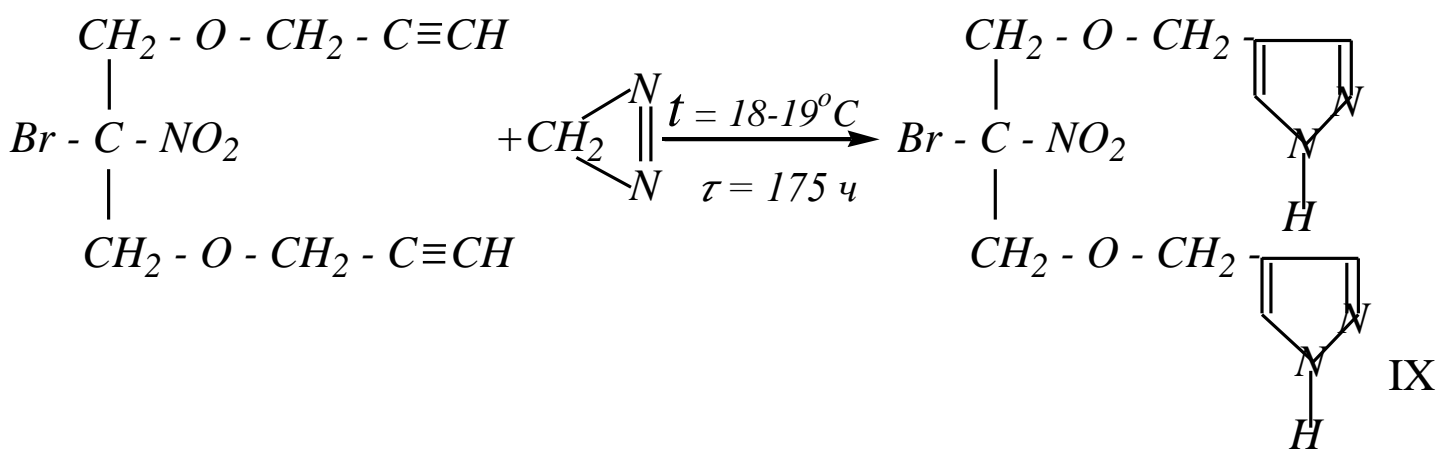

4,4' - bis (pyrazolyl-hydroxymethylene) 2-bromo-2-nitro-1,3-propanediol - (IX) the structure of the obtained compound was confirmed by elemental analysis and IR-spectroscopy.

Physico-chemical parameters are given in table. 5.

Table 5. In the IR-spectra, characteristic absorption bands are observed in the region typical of the pyrazole ring in the region of $1612,1122,924 \mathrm{~cm}^{-1}$.

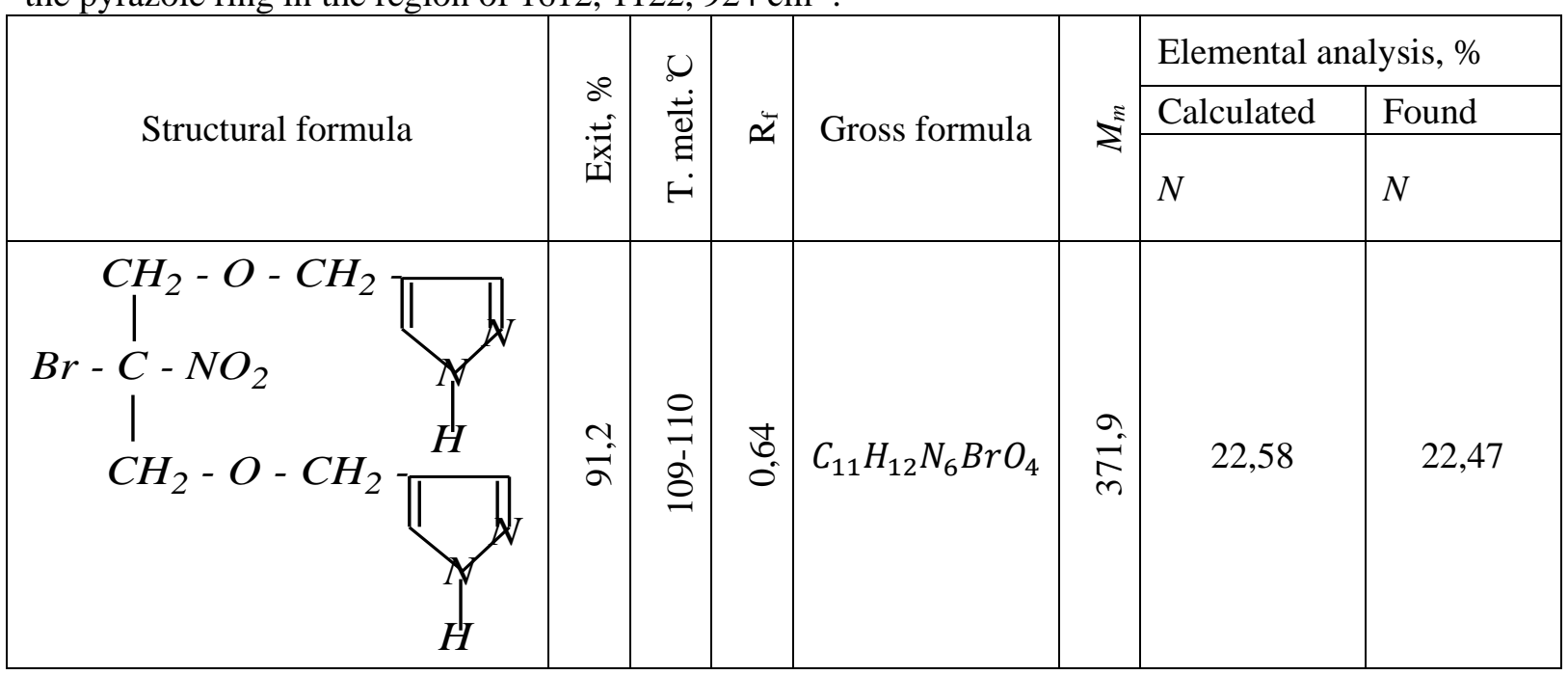


The aromaticity of the cycle is preserved, but the ability to electrophilic substitution at carbon atoms decreases sharply. At the same time, the presence of undivided pairs in heteroatoms increases the probability of an electrophilic attack on nitrogen, contributing to tautomeric transformations and the formation of quaternary salts.

The mutual influence of the lone electron pairs of heteroatoms and the $\pi$-electron sextet of the ring is even more important in determining the inclined ability of these heterocycles, 1,2-pyrazoles exhibit weak acidic properties.

Thus, the reflected achievements and modern level of work in the field of chemistry of derivatives of heterocyclic systems convincingly show and prove that in recent years, methods for the synthesis of heterocyclic esters of 1,2-pyrazole or 1,2-pyrazoline have been actively developed. The rings of 1,2pyrazole (or 1,2-pyrazoline) are extremely stable, and many of its derivatives can be distilled without decomposition and melting. Data of the IR-spectra of compounds (IX) are shown in table 6.

Table 6. IR-spectra of compounds (IX).

\begin{tabular}{|c|c|c|c|c|c|}
\hline \multirow{3}{*}{ № compound } & \multicolumn{5}{|c|}{ IR-spectra, $\mathrm{v}, \mathrm{cm}^{-1}$} \\
\cline { 2 - 6 } & & $\mathrm{C}-\mathrm{Br}$ & $-\mathrm{N}-$ & & \\
& & $\mathrm{H}$ & $-\mathrm{O}-\mathrm{CH}_{2}-$ & & $\mathrm{C}-\mathrm{NO}_{2}$ \\
& & & & $1612,1118,925$ & $1557-1369$ \\
\hline IX & 664 & 3412 & 1228 & \\
\hline
\end{tabular}

Thus, the introduction of a triple bond led to the appearance of a gamma of a variety of pharmacological, physiological, and biological activities, as well as the ability to inhibit metal corrosion, the formation of complex compounds, the formation of polymers, and much more.

The interaction of compound (IX) with hexamethylene diisocyanate (X).

Diisocyanates are among the compounds having an extremely super-high reactivity. Secondary amines with heterocyclic groups containing $\mathrm{N}-\mathrm{H}$ bonds have the highest reactivity with respect to the isocyanate [14-16].

We were the first to obtain derivatives of the tetraurea of the interaction of hexamethylenediisocyanate with compound (IX) at a temperature of $50-55^{\circ} \mathrm{C}$ according to the scheme:

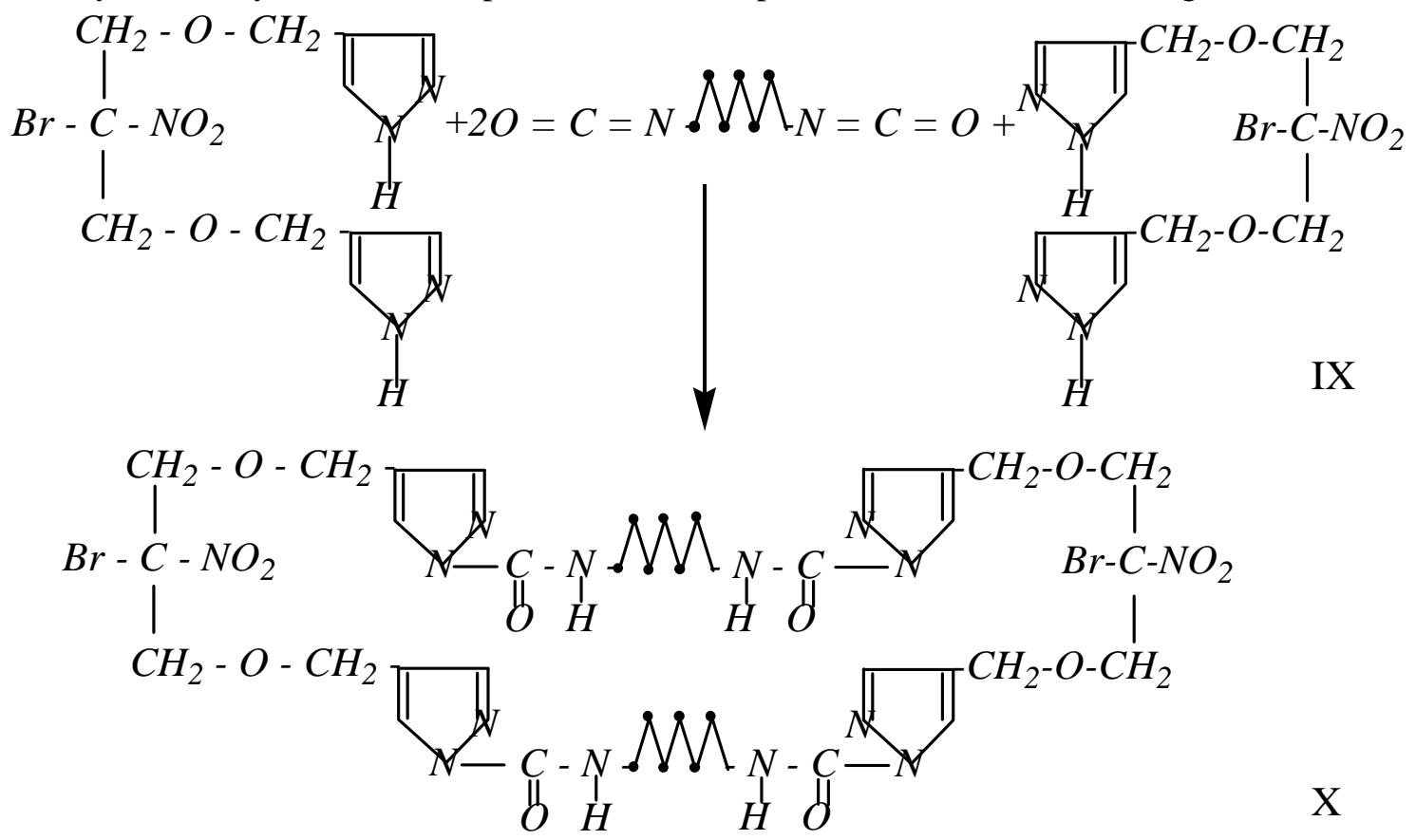

The synthesis was carried out in dimethylformamide at a temperature of the reaction medium of $50-52{ }^{\circ} \mathrm{C}$ for $3.0-3.5$ hours. It should be noted that the new environmentally friendly tetraurea derivatives are obtained in the form of a snow-white powdery product $(\mathrm{X})$, with fairly high yields, without waste.

Physico-chemical characteristics of compounds (X) are given in table. 7. 
Table 7. Physico-chemical parameters of the drug (X).

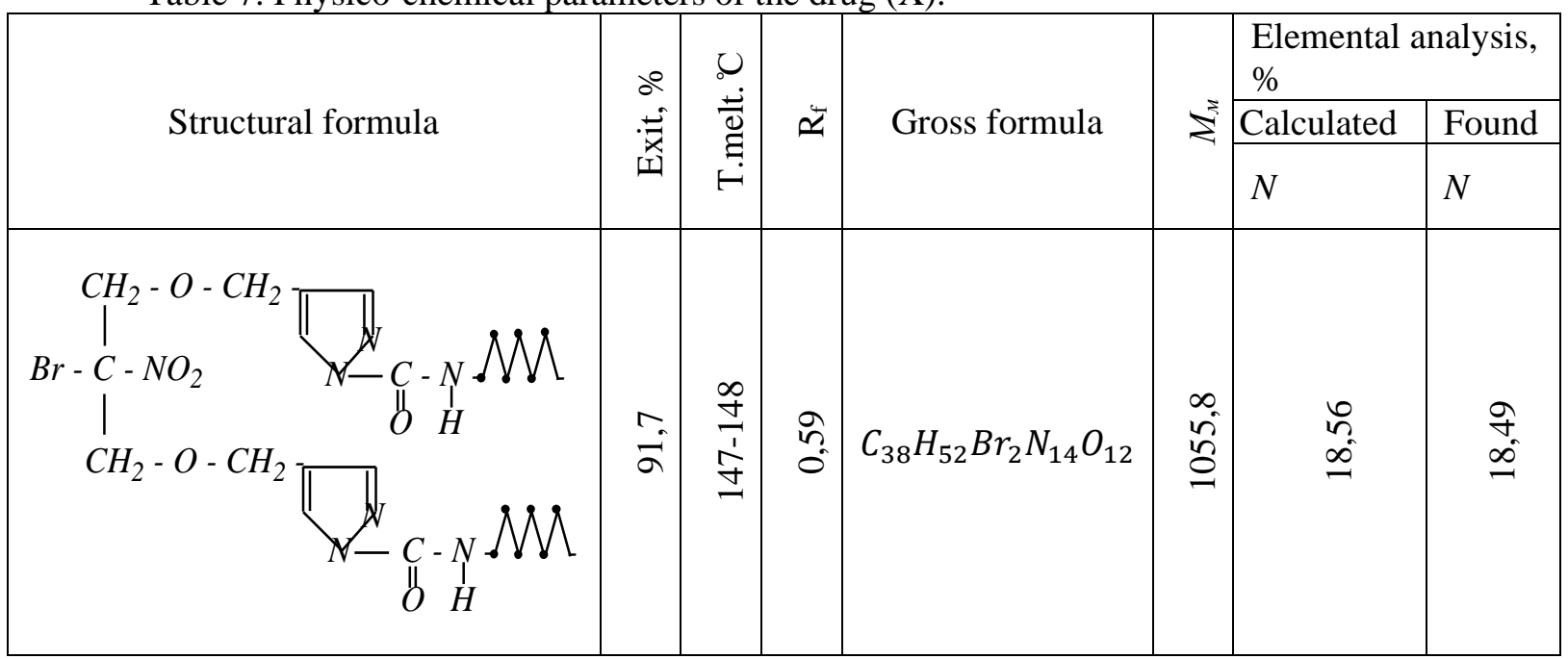

Compounds were purified by recrystallization from ethyl alcohol. The identity of compounds (X) was established by TLC on Silitol plates.

The following systems were used as eluents:

System I: $\mathrm{CHCl}_{3}: \mathrm{CH}_{3} \mathrm{OH}: \mathrm{HCOOH}=9: 1: 0,3$;

System II: $\mathrm{HCOOH}: \mathrm{CH}_{3} \mathrm{COCH}_{3}: \mathrm{CCl}_{4}=0,7: 6,0: 0,5$;

Structure $\left\{\right.$ bis - (N, N '- hexamethylene) $\left[\alpha, \alpha^{\prime}, \alpha, \alpha^{\prime}\right.$ - tetra-hydroxymethylene - 4.4', 4.4' tetrapyrazolilo - $1.1^{\prime}, 1.1^{\prime}$ - tetra urea] - bis - ( $\beta$ - bromo -, $\beta$ - nitro - propane) $\}(\mathrm{X})$ is confirmed by the data of elemental analysis, as well as IR- and PMR- spectroscopy. In the IR-spectrum of compounds (X), there is a wide absorption band in the region of $1716 \mathrm{~cm}^{-1}$ characteristic of the $-C=O$ group, and the absorption band in the region of $1626 \mathrm{~cm}^{-1}$ corresponds to the absorption of $/ N-C-N-$ strong absorption band in the region of $3307 \mathrm{~cm}^{-1}$ is characteristic of $N-H$ groups (Table 8).

Table 8. IR- and PMR-spectra of compounds (X).

\begin{tabular}{|c|c|c|c|c|c|c|c|c|c|c|c|}
\hline \multirow[b]{2}{*}{$\begin{array}{c}\text { № } \\
\text { compound }\end{array}$} & \multicolumn{8}{|c|}{ IR-spectra, $v, \mathrm{~cm}^{-1}$} & \multicolumn{3}{|c|}{ PMR-spectra, $\delta$, ppm. } \\
\hline & $\mathbf{v}-\mathbf{z}$ & $\begin{array}{l}\mathbb{J}^{N} \\
1 \\
0 \\
1\end{array}$ & $H$ & 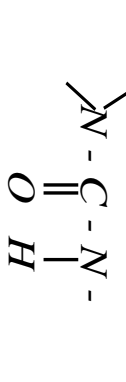 & $\frac{1}{1}$ & $\begin{array}{l}\stackrel{0}{I} \\
\stackrel{N}{I} \\
\stackrel{I}{I}\end{array}$ & $\begin{array}{l}0^{N} \\
z_{0} \\
0\end{array}$ & $\begin{array}{l}\text { Dे } \\
\text { 1 }\end{array}$ & $\begin{array}{c}1 \\
1 \\
\mathbb{Z} \\
1 \\
N \\
\mathbb{U} \\
1 \\
0 \\
1 \\
-1\end{array}$ & $\begin{array}{c}n \\
1 \\
1 \\
1 \\
0 \\
n \\
N\end{array}$ & $-\frac{1}{z_{1}^{2}}$ \\
\hline$X$ & હ্లి & 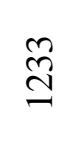 & 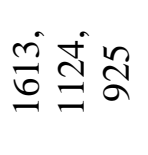 & ర్ర & $\underset{\substack{\infty \\
\infty}}{\stackrel{\infty}{N}}$ & \begin{tabular}{l}
$\bar{n}$ \\
\multirow{2}{0}{} \\
$\stackrel{0}{r}$
\end{tabular} & $\begin{array}{ll}\dot{1} & \infty \\
& 0 \\
2 & 0\end{array}$ & రి & $\begin{array}{l}\vec{\infty} \\
i\end{array}$ & 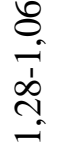 & ते \\
\hline
\end{tabular}

\section{Experimental part.}

1. Synthesis of 2-bromo- 2-nitro-dipropargyl diester of 1,3-propanediol: (I) In a flask equipped with a reflux condenser $20.0 \mathrm{~g}$ (0.1 mol) of 2-bromo, 2-nitro-propanediol-1,3, $23.8 \mathrm{~g} / \mathrm{mol}$ of freshly brewed propargyl bromide, $30 \mathrm{~g}$ of calcined potassium carbonate and $350 \mathrm{ml}$ of anhydrous acetone as solvent was placed, the reaction mixture was heated in a water bath at $90^{\circ} \mathrm{C}$ for 8 hours and left overnight. The mixture was filtered, the product was removed from the filtrate with ether. After evaporation of the solvent, the precipitate was recrystallized from benzene. Obtained by the specified method, 2-bromo-, 2-nitro-dipropargyl diester of propanediol-1,3 - colorless with T. melting. $=56-57^{\circ} \mathrm{C}$. The yield of product $(\mathrm{I})$ is $82.3 \%$ (of theoretical). $\mathrm{R}_{\mathrm{f}}=0.71$; 
Found,\%: $\quad C$ 37.97; $\mathrm{H} \mathrm{3.47;} \mathrm{Br} 28.79 ; \mathrm{N}$, 4.97;

Calculated for $\mathrm{C}_{9} \mathrm{H}_{10} \mathrm{BrNO}_{4}, \%$ :, $\mathrm{C} \mathrm{39.14;} \mathrm{H} \mathrm{3.62;} \mathrm{Br} 28.96$; $\mathrm{N}, 5.07$;

2. Synthesis of $\gamma, \gamma^{\prime}$-diphene (2-bromo-2-nitro-dipropargyl diester) propanediol-1,3 (II).

Copper chloride, taken with a $25-30 \%$ excess, is completely dissolved in $25 \%$ ammonia with the addition of a small amount of hydroxylamine hydrochloride.

The prepared copper chloride solution is added to a dilute alcohol solution of $20.0 \mathrm{~g}$ of 2bromo, 2-nitro-dipropargyl diester-propanediol-1,3. The resulting bright yellow precipitate was filtered off and washed with a weak solution of hydroxylamine hydrochloride, water and sulfuric ether. The precipitate is dried in an oven at $50{ }^{\circ} \mathrm{C}$ [].

3. Synthesis of $\gamma, \gamma^{\prime}$-bis- (silver 2-bromo-, 2-nitro-dipropargyl ether) - propanediol-1,3 (III).

To an alcohol solution of $2.0 \mathrm{~g}(0.01 \mathrm{~mol})$ of 2-bromo-, 2-nitro-dipropargyl diester propanediol-1,3 was added an alcoholic solution (calculated) of silver nitrate. Quickly precipitated slightly colored precipitate was filtered, washed with alcohol and water. The product was dried at 64 $70^{\circ} \mathrm{C}$ in an oven. Yield (III) quantitative:
Found,\%:
Ag 43.91;

Calculated for $\mathrm{C}_{9} \mathrm{H}_{8} \mathrm{Ag}_{2} \mathrm{NBrO}_{4}, \%: \mathrm{Ag} 44.06$;

4. Synthesis of mercury-bis- (propargyl ether) - 2 - bromo- 2-nitro-propanediol - 1.3 (IV).

In a three-necked flask equipped with a reflux condenser, a stirrer and a dropping funnel, $10 \mathrm{~g}$ of mercury acetic acid, $22 \mathrm{~g}$ of potassium iodide, $50 \mathrm{ml}$ of water were placed and heated to complete dissolution, after which $18 \mathrm{ml}$ of $10 \%$ sodium hydroxide solution were added. $2.0 \mathrm{~g}(0.01 \mathrm{~mol})$ of 2bromo- 2-nitro-dipropargyl diester-propanediol $-1.3 \mathrm{in} 50 \mathrm{ml}$ of methanol was added to the solution with continuous stirring over 30 minutes. A crystalline precipitate of the mercury derivative gradually precipitated. The precipitate was filtered off, washed with $50 \mathrm{ml}$ of methanol and repeatedly with water. After drying, a light grayish powder with T. melting. $=194-195^{\circ} \mathrm{C}$ (decomp.). The yield of product (IV) is $88.6 \%$ (of theoretical).

Found, \%:

Hg 42.13;

Calculated for $\mathrm{C}_{9} \mathrm{H}_{8} \mathrm{HgNBrO}_{4}, \%: \mathrm{Hg} 42.27$;

5. Preparation of $\gamma, \gamma^{\prime}$-diiod- dipropargyl diester - 2-bromo- 2-nitropropanediol-1,3 (V).

A two-necked flask was equipped with a stirrer and a conventional glass funnel. $40.0 \mathrm{~g}(0.1$ mol) are placed in the flask above the obtained precipitate $\gamma, \gamma^{\prime}$-diphene - (2-bromo-2-nitro dipropargyl diester) - propanediol $-1,3$ and $250 \mathrm{ml}$ of dry diethyl ether. To a suspension of diacetylenide (II) in ether, $25.4 \mathrm{~g}(0.05 \mathrm{~g} / \mathrm{mol})$ of metallic iodine are added in small portions with vigorous stirring. Each subsequent portion is added after bleaching the solution. The precipitate was filtered, the ether was distilled off, the crude product (V) was purified by recrystallization from methanol. The yield of the product $\left(\gamma, \gamma^{\prime}\right.$-diiod --dipropargyl diether) is 2-bromo-, 2-nitropropanediol$1,3(\mathrm{~V})-94.7 \%$ (of theoretical). $\mathrm{R}_{\mathrm{f}}=0.71$;

Found, \%:

C 20.33; H 1.44; $\mathrm{Br} 15.03 ; \mathrm{N}, 2.44 ;$ I 47.93;

Calculated for $\mathrm{C}_{9} \mathrm{H}_{8} \mathrm{I}_{2} \mathrm{BrNO}_{4}, \%$ : $\mathrm{C} 20.46 ; \mathrm{H} \mathrm{1.51;} \mathrm{Br} \mathrm{15.14;} \mathrm{N} 2.65 ; \mathrm{I} 48.09$;

6. Synthesis of $\gamma, \gamma^{\prime}$-dibromo-(dipropargyl diester) - 2-bromo-2-nitropropanediol-1,3 (VIII).

According to the above procedure, $4.76 \mathrm{~g}(0.01 \mathrm{~g} / \mathrm{mol})$ of mercury - bis - (propargyl ether) - 2 - bromo -2-nitro - propanediol - 1,3 (IV) in $40 \mathrm{ml}$ of carbon tetrachloride was added dropwise $0.58 \mathrm{~g}$ of bromine in $5 \mathrm{ml}$ of $\mathrm{CCl}_{4}$ for 20 minutes. After completion of the reaction, the reaction mixture was filtered, the solvent was distilled off, the residue was recrystallized from $\mathrm{CCl}_{4} \cdot \gamma, \gamma^{\prime}$-dibromodipropargyl diester - 2-bromo-, 2-nitropropanediol-1,3 - grayish-colored powder with a $\mathrm{T}$ melting. $=$ $39-40^{\circ} \mathrm{C}$. The product yield of $\gamma, \gamma^{\prime}$-dibromo-dipropargyl diester - 2-bromo-2-nitropropanediol-1,3 (VIII) $-82.4 \%$ (of theoretical). $\mathrm{R}_{\mathrm{f}}=0.70$;

Found,\%: $\quad B r 55.11$;

Calculated for $\mathrm{C}_{9} \mathrm{H}_{8} \mathrm{Br}_{3} \mathrm{NO}_{4}, \%: \mathrm{Br} 55.28$; 1,3 (IX).

7. Preparation of bis- $\left(4,4^{\prime}\right.$-pyrazolyloxymethylene $)$ - 2 - bromo - 2 - nitro - propanediol -

$20.0 \mathrm{~g}(0.1 \mathrm{~mol})$ of dipropargyl diester - 2 - bromo -2 - nitro - propanediol - 1.3, previously dissolved in $300 \mathrm{ml}$ of diethyl ether, are added to a conical flat-bottomed flask, then $2 \mathrm{~g}(0.05 \mathrm{~mol})$ of a freshly prepared solution of diazomethane in $30 \mathrm{ml}$ of diethyl ether are gradually poured in small portions. The reaction mixture is placed in a dark, dark place at a temperature of $17-18^{\circ} \mathrm{C}$. The mixture is left for 8 to 9 days, and as the yellow color of the diazomethane solution disappears, its new portions 
are added until a triple bond with the ammonia solution of copper monochloride is negative, then the solvent is evaporated, the product is purified by TLC on alumina in the benzene system: hexane $=1: 3$; the target product is a crystalline substance with a melting point of $109-110^{\circ} \mathrm{C} . \mathrm{R}_{\mathrm{f}}=0.64$;

Found, \%:

$C$ 35.51; $\mathrm{H} \mathrm{3.16;} \mathrm{Br} 21.36 ; \mathrm{N}, 22.59$;

Calculated for $\mathrm{C}_{11} \mathrm{H}_{12} \mathrm{~N}_{6} \mathrm{BrO}_{4}, \%$ : $\mathrm{C} 35.49 ; \mathrm{H} \mathrm{3.22;} \mathrm{Br} 21.48 ; \mathrm{N}, 22.58$;

8. Preparation of bis - (N, $N^{\prime}$ - hexamethylene) [ $\alpha, \alpha^{\prime}, \alpha, \alpha^{\prime}$ - tetra-hydroxymethylene $4.4^{\prime}, 4.4^{\prime}$ - tetrapyrazolilo - $1.1^{\prime}, 1.1^{\prime}$ - tetroureas] - bis - ( $\beta$ - bromo - $\beta$ - nitro-propane) (X).

In a three-necked flask equipped with a reflux condenser, a thermometer, and a stirrer,7.44 $\mathrm{g}$ (0.02 mol) of bis - (4.4' - pyrazolyl-hydroxymethylene) - $\beta$ - bromo- $\beta$ - nitro - $\alpha, \alpha^{\prime}$ - propanediol are placed then $25 \mathrm{ml}$ of triethylamine, $40 \mathrm{ml}$ of DMF are added at a temperature of $40-47^{\circ} \mathrm{C}$, while stirring, $1.7 \mathrm{~g}(0.011 \mathrm{~mol})$ of hexamethylene diisocyanate dissolved in $8 \mathrm{ml}$ of DMF are added dropwise. The reaction mixture is stirred for 3.0 hours at a temperature of the reaction mixture of 49 $53^{\circ} \mathrm{C}$. After the time, the contents of the flask are transferred to a glass, water is added. The precipitate was washed with TLC. After drying, a slightly colored powder is obtained with a yield (X) of $91.7 \%$ (of theoretical). T.melting $=147-148{ }^{\circ} \mathrm{C} ; \mathrm{R}_{\mathrm{t}}=0.59$;

Found, \%:

C 43.06; $\mathrm{H} 4.79 ; \mathrm{N}, 18.49 ; \mathrm{Br} 15.02$;

Calculated for $\mathrm{C}_{38} \mathrm{H}_{52} \mathrm{Br}_{2} \mathrm{~N}_{14} \mathrm{O}_{12}, \%: \mathrm{C} 43.19 ; \mathrm{H} \mathrm{4.92;} \mathrm{N}, 18.56$; $\mathrm{Br} 15.13$;

Conclusions. The currently intensively developing chemistry of acetylene derivatives of pyrazolyl urea compounds has attracted the attention of many researchers, both in the Republic of Uzbekistan and around the world [14-16].

This is connected, on the one hand, with the rich possibilities of various chemical transformations that acetylene, urea, and pyrazole groups provide in the molecules of organic compounds, and, on the other hand, with the properties of the most organic compounds with the above-mentioned groups that are valuable for practical use.

There are many examples where the introduction of a triple bond led to the appearance of a gamma of various pharmacological, physiological and biological activities, as well as the ability to inhibit metal corrosion to form complex compounds, form monomers, polymers, and much more.

The further development of acetylene 1,3-propanediol, and their derivatives, is an extremely urgent task of the 21 st century.

\section{REFERENCES}

1. Makhsumov A.G., Holboev Yu.Kh., Valeeva N.G., "Synthesis of the technology of the properties of bis urea derivatives and their application", monograph, Latvia, Riga, 2019, p. 1-118.

2. Makhsumov A.G., Ismatov D.N., Valeeva N.G., Asadova R.D., Rusmetov B. Modern advences in the synthesis of new derivatives of acetylene dithiocarbamate and their biological activaty // International Journal of Engineering and scientitic research, 2019, vol.7, Issue 4, april, p.13-21.

3. Auesbaev A.U., Makhsumov A.G. Obtaining nitromethane in laboratory conditions // XXVII -ITA "Umidli kimyogarlar - 2019", Tashkent, 2019, p. 199

4. Kholboev Yu.Kh., Makhsumov A.G., Inakov T.K. Synthesis and development of technology for producing N, N 'hexamethylene bis - [(aminoaroyl) urea] and their properties." // monograph, Andijan, 2018, pp. 1-120.

5. Yuan Jun, Zeng Ying, Xianmin. A new synthetic method of bronopol // J.Fine chemicals 14, p. 47-48.

6. Ван Цзиньбан, Фу Циноу, Ван Сюлин. Fine chemicals, 5(4), p.21, (1988).

7. Чжу Юйцин, Guangzhou chemical, 22(2), p.5 (1994).

8. Сюй Лиин. Цзянсуская химическая промышленность (1), p. 55 (1990).

9. Sh. R. Saydaxmetova, A. G. Makhsumov. Organic Chemistry, Textbook, Tashkent, 2019, p. 137.

10. K. Khaydarov, A. G. Makhsumov, M. G. Maksumova, M. A. Nurmukhammedova, N. G. Valeeva. Pharmacological activity of bromo - phenyl derivatives of substituted pyrazoles // International Jounal of advanced research in science, engineering and technology", vol.6, Issue 10, October 2019, pp. 11113-11119.

11. Makhsumov A. G., Muhiddinov B. F., Ismatov D. N., Ismailov B.M. Synthesis and transformations of tripropargylether of gallik acid // Mater. RSTC: "Current problems and prospects of chemistry and chemical and metallurgical production", Novoi, 2018, pp. 72-73.

12. Li Fugang Wang, Shiwei Mi Chaojie, Yu Dongmao. Method for preparing bronopol through catalyzing by solid base [P] CN:102627566A 2012-08-08.

13. Makhsumov A. G., Valeeva N. G., Absalyamova G. M., Xolikova S. D. Synthesis and research of $N, N^{\prime}-$ he[fvethylene bis ${ }^{1}-\left\{\right.$ bis $^{2}-\left[2,2^{\prime}-(\right.$ phenylazo $)-1,1^{\prime}-($ naphthol $)$ - glyceryl $-2,2^{\prime}-$ dioxy $-\beta$ - ола] carbamate\}, its property and application // International Journal of advanced research in science, Engineering and Technology, vol.6, Issue 5, May 2019, pp. 9395-9405.

14. Li Jiansheng, Li Xia, Zhang Chengyu. Synthetic method for bronopol [P]. CN:104926661A 2015-05-27. 
15. Gunter Scherr, Ludwigshafen (DE); Thomas Bogenstatter, Bad Durkheim 7 (DE); Jurgen Huff, Ludwigshafen (DE). Method for the continuous production of 2-bromo-2-nitro-1,3-propanediol [P] US:20040186326A1 2004-09-23.

16. Michio Harakawa, Osamu Takatsuka. Preparation of 2-bromo-2-nitro-1,3-propanediol [P] JPS:572242A 1982-01-07.

17. Bronopol, a broad spectrum antibacterial agent, technical bulletin, The boats Co., Nottingham, (1966).

18. Pharmaceutical Uses of Boots Biocids, Technical Bulletin, the boots Co., Nottingham (1984).

19. K. D. Brandt. Materials of Great Britain technology week in USSR, Moskow (1984), pp. 49-54.

20. John B Tindall, Terre Haute. Nitroalkanols from nitroalkanes and formaldehyds [P]. US:3534112, 1970-10-13.

21. G. Ya. Legin, N. M. Shekhtman, and V. M. Andreev, Reeview Information of tsNiiteip [in Russian], Ser.8, No. 3, Moskow (1983).

22. B. Croshaw, V. R. Holland. Cosmet. Sci. technol Ser., No. 1 (Cosmet. Drug Preserv.), 31-62 (1984).

23. J. Turner, Parfums. Cosmet., Aromes, No. 82, 93-98 (1989).

24. B. Croshaw, M. J. Groves, B. Lessel. J. pharm. Pharmacol., 16, Suppl., 127 - 130 (1964).

25. M. L. Henry. Rec. trav. Chin., 16, 250 - 252 (1987).

26. D. M. Bryce, B. Croshaw, J. E. Hall, et al., J. Soc. Cosmet chem., 29, (1), 3-24 (1978).

27. D. S. Gowda, R. Rudman. J. chem. Phys., 77(9), 4666 - 4670, 4671 - 4677 (1982).

28. E. Schmidt, R. Wilkendorf. Chem. Ber., 52, 389 - 399 (1919).

29. J. C. Toler. Intern. J. Cosmet. Sci., 7 (4), 157 - 164 (1985).

30. S. S. Novikov, G. A. Shveikgeimer, V. V. Sevostyanova, et. al., The chemistry of aliphatic and alicyclic nitrocompounds [in Russian], Moscow (1974).

31. Snito H., T. Onoda. Antibacterial action of bronopol on various bacteria, especially on pseudomonas aeruginosa // chemotherapy (Tokyo), 1974, 22, p.1466 - 1473.

32. Croshaw B., M. J. Goves,, B. Lessel. Некоторые свойства бронопола нового противомикробного средства против pseudomas aeruginosa // J. Pharm. Pharmacol., 1964, 16, p. 127.

33. Storrs F. J., D. E. Bell. Allergic contact dermatitis to 2 - bromo - 2 - nitropropan - 1,3 - diol // J. Amer. Acad. Dermatov, 1983, 8, p. 157 - 170.

34. Richard Wessendorf, H. Rhineland. Процесс по производству Halonitro alcohols // Dusseldorf - Helt, Germany, Filed July 17, 1969, Ser № 842711.

35. Reregistration Eligibility decision: Bronopol, office Resticide programs, 1995, pages 2 - 3 .

36. "2 - Bromo - 2 - nitropropane - 1,3 - diol", cosmetics INFO. Org, the Personal Care Products.

37. S. S. Novikov, G. A. Shveikgeimer, V. V. Sevostyanova, et. al., The chemistry of aliphatic and alicyclic nitrocompounds [in Russia], Moscow (1974). 